\title{
Value of Magnetic Resonance Imaging and Audiology in the Emergency Department in Differential Diagnosis of Peripheral and Central Vertigo
}

\author{
Periferik ve Santral Vertigo Ayırımında \\ Odyoloji ve Manyetik Rezonans Görüntülemenin \\ Acil Serviste Kullanımının Değeri
}

Engin ÖZAKIN, MD, Msc, ${ }^{a}$ Figen COȘKUN, MD, Assoc.Prof., ${ }^{a}$ Sarp SARAÇ, MD, Prof., ${ }^{b}$ Kader KARLI OĞUZ, MD, Assoc.Prof.,o Şebnem BOZKURT, MD, Msc ${ }^{\mathrm{a}}$

Departments of

aEmergency Medicine,

'ENT,

'Radiology,

Hacettepe University Faculty of Medicine, Ankara

Geliş Tarihi/Received: 24.08 .2010 Kabul Tarihi/Accepted: 11.06.2011

Yazışma Adresi/Correspondence: Engin ÖZAKIN, MD, Msc Hacettepe University Faculty of Medicine, Department of Emergency Medicine, Ankara,

TÜRKIYE/TURKEY

enginozakin@hotmail.com

\begin{abstract}
Objective: Vertigo is a common complaint in the emergency room. Vertigo can be central or peripheral in origin and it is important for an emergency physician to make a correct differential diagnosis. The purpose of our study was to emphasize the role of cranial magnetic resonance imaging (MRI) and audiological tests in differential diagnosis of patients who present with vertigo to the emergency room. Material and Methods: Fifty patients (31 female, 19 male, mean age 50.84 years) with vertigo who were admitted to the Hacettepe University Faculty of Medicine Emergency Room (ER) between 01.10.2004 and 31.01.2005 were included in the study. Physical and neurological examinations of all patients were performed by senior residents and all patients were evaluated by Ear Nose Throat specialists. Audiologic and vestibular tests and MRI with 3T (Tesla) magnetic field power were performed in all patients. Results: Among 29 patients with normal neurological examination, only 3 (10.3\%) had lesions on MRI. MRI scans revealed lesions suggesting central vertigo etiology in six (18.2\%) patients out of 33 with abnormal audiological test suggesting peripheral vestibulopathy. Conclusion: In conclusion, in our prospective study, urgent cranial MRI technique in patients presenting to the emergency room with vertigo may reveal significant findings regarding the differential diagnosis and concomitant pathologies. However, meticulous neurological examination can exclude central vertigo in the majority of the patients.
\end{abstract}

Key Words: Vertigo; emergencies; magnetic resonance imaging

ÖZET Amaç: Baş dönmesi, acil serviste sık karşılaşılan bir yakınmadır. Baş dönmesi santral veya periferik kaynaklı olabilir. Çalışmamızın amacı, acil servise baş dönmesi şikâyeti ile başvuran hastalarda kraniyal manyetik rezonans görüntüleme (MRG) yönteminin ve odyolojik testlerin ayırıcı tanıdaki önemini ortaya koymaktır. Gereç ve Yöntemler: Çalışmaya, 01.10.2004-31.01.2005 arasında baş dönmesi yakınması ile Hacettepe Üniversitesi Erişkin Hastanesi Acil Servise başvuran 31 kadın, 19 erkek (yaş ortalamaları 50,84 yıl) toplam 50 hasta alınmıştır. Tüm hastaların fizik ve nörolojik muayenesi acil servis kıdemli hekimi tarafından yapılıp, kulak burun boğaz (KBB) uzmanlarınca değerlendirilmiştir. Tüm hastalara odyovestibüler tetkikleri yapılmış ve 3 tesla manyetik alan gücüne sahip cihazla MRG çekilmiştir. Bulgular: Normal nörolojik muayeneye sahip 33 hastanın sadece 3'ünde (\%10,3) MRG'de lezyon mevcuttu. Periferik vestibulopati düşünülen 33 hastanın 6'sında santral vertigo ile ilişkili lezyon saptandı. Sonuç: Sonuç olarak, ileriye dönük bu çalışmada, baş dönmesi ile başvuran hastalarda acil kraniyal MRG yönteminin, ayırıcı tanı ve ek patolojilere yönelik olarak önemli bulgular sunduğu gösterilmiştir. Ancak dikkatli bir nörolojik muayene ile hastalığın santral vertigo olasılığı dışlanabilir.

Anahtar Kelimeler: Vertigo; aciller; manyetik rezonans görüntüleme

Turkiye Klinikleri J Med Sci 2012;32(1):1-6

-ertigo is one of the most common complaints among patients referring to the emergency room (ER), and it is not always easy to define the underlying disorder because of the complexity of structure and 
functioning of the systems responsible for the balance of the organism. ${ }^{1-3}$ Patients frequently refer to the term "vertigo" to define their various complaints, since the extent of this term is not clearly defined; therefore, vertigo is a very common complaint. The true equivalent for vertigo in terms of general public is "feeling unsafe". 1,4 Although not a real motion, vertigo is the exaggerated or fictitious sensation of motion of the patient. ${ }^{5,6}$ Patients can describe themselves as swaying or moving or the surrounding environment as moving or room spinning. Vertigo can be confused with dizziness, syncope, near-syncope, tiredness or some psychiatric conditions. ${ }^{7,8}$

Although the objective was to identify the underlying etiology in patients presenting with vertigo, this aim was not achieved directly. In these situations, patient should be evaluated from basic to complex, proceeding from undifferentiated systems to specialized systems. The clinician should try to differentiate the etiology of vertigo, and to define whether the pathology originated from vestibular or extra-vestibular systems, depending on the patient's history and background..$^{9}$ Later, he/she should investigate whether the peripheral or the central vestibular system is involved.

Patients whose neurological examination suggests an intracranial event are assessed with cranial computerized tomography (CCT). However, CCT is not always helpful in the discrimination of peripheral and central causes of vertigo. CCT is not as sensitive as magnetic resonance imaging (MRI) in identifiying intracranial conditions that could clinically present with vertigo such as cerebellar ischemic lesions, demyelinizing diseases, intracranial mass lesions, pontocerebellar lesions, and mass lesions of the $7^{\text {th }}$ and $8^{\text {th }}$ cranial nerves. Besides, in cases with a suspicion of peripheral vertigo, MRI is electively planned after consulting the ear-nosethroat (ENT) department. However, elective MRI can cause a delay in the diagnosis in these patients where early diagnosis and treatment is essential for a low mortality and morbidity.

Therefore, we aimed to identify the criteria for urgent assessment of audiological tests and MRI ac- cording to data obtained with history and physical examination in patients resenting to the ER with vertigo. We hope that the criteria set in this study will facilitate the diagnosis and treatment of conditions with high mortality and morbidity without delay, since audiological tests and MRI cannot be run in every patient referring to the ER due to costeffectiveness and time restrictions.

\section{MATERIAL AND METHODS}

Fifty consecutive patients referring to the Hacettepe University Hospital Adult Emergency Room between 01.10.2004 and 30.01.2005 with vertigo were assessed prospectively. This study was approved by the Local Ethics Commitee of the Hacettepe University. Informed consents were obtained from each patient. All patients presenting with peripheral and central vertigo were included in the study. Patients younger than 16 years, those with vertigo due to metabolic and hematological conditions, pregnant cases, patients with vertigo with known etiology, unstable patients due to other causes, and patients who were not suitable for MRI were excluded from the study.

Age, gender, complaint, onset of symptoms, history of previous attack, medications, concomitant illnesses, previous surgery, and habits of the patients were noted. Included patients were assessed and examined by emergency room senior resident and obtained data were recorded in the previously prepared forms. The patients were consulted with physicians from the Ear-Nose-Throat (ENT) department and audiovestibular tests were performed in the audiology unit prior to initiation of treatment. Audiological tests measured pure speech audiometry, acustic reflex, speech discrimantion scores (SDS), and cochlear sensitivity (disturbance from sound intensity of 90 decibel or less in hearing test). Loss of hearing in lower frequencies and presence of cochlear sensitivity in hearing tests were considered in favor of peripheral vestibulopathy. In vestibular tests, Romberg test, cerebellar tests, walking on a straight line, and Dix-Hallpike maneuver were performed for positional nystagmus. These tests were evaluated by an ENT specialist. After ENT consultation, the pa- 
tients underwent cranial MRI screening with 3 tesla magnetic field power machine (Allegra, Siemens, Erlangen, Germany). First, T2weighted Turbo Spin-Echo imaging method with 20 slices of $1 \mathrm{~mm}$ intervals and $5 \mathrm{~mm}$ thickness on transverse plain was obtained in order to rule out intracranial pathologies such as tumor, demyelinating diseases, hydrocephaly and cortical infarction (T2WTSE) (Time to repeat (TR)/echo time (TE): 4000/100 msec, matrix: 128x256). Later, diffusion-weighted imaging (DWI) effective in identification of acute ischemic lesions (TR/TE; 2800/78, b: 0,500/1000 $\mathrm{mm}^{2} / \mathrm{sec}$ ) and three dimensional constructive interference in steady state (CISS) for imaging of cerebellopontine angle cysterns, internal acustic canals, mass lesions of the $7^{\text {th }}$ and $8^{\text {th }}$ nerve complexes (TR/TE; 7.6/3.8. Flip angle: $48^{\circ}$ ) were performed. Images were reviewed by a neuroradiologist. In case of presence of other intracranial pathologies, scan was repeated according to the lesions detected. In patients diagnosed with peripheral vertigo with a negative MRI result, appropriate treatment was started with follow-up by ENT consultation. Patients diagnosed with central vertigo were consulted to the relevant department and further treatment was provided.

Mean standard was calculated to assess the demographic features of patients; Marginal Homogeneity Test and McNemar Test were used to compare the data. For all tests $\mathrm{p}<0.05$ was considered statistically significant. Statistical data were used to find out which patients should be evaluated with audiological tests and MRI. SPSS for Windows 15.0 statistical software was used for analysis of data.

\section{RESULTS}

Fifty patients presenting to the ER consecutively between 01.10.2004 and 31.01.2005 were included in the study. Nineteen patients (38\%) were males, and $31(62 \%)$ were females. Mean age of the patients was 50.84 years (minimum 17 years, maximum 87 years, median 50 years).

Thirty-three patients presented with vertigo, nausea and vomitting, 1 patient had tinnitus, 5 patients had ear pressure, 4 patients had tinnitus and ear pressure, and 7 patients had tinnitus and hearing loss.

Onset of symptoms was within minutes in 2 patients, within hours in 40 patients, and within days in 8 patients, and history of previous attack was present in 24 patients. History of medication was absent in 31 patients, whereas 9 patients were on medication for cardiovascular system diseases, 2 patients for neurological system diseases, 4 patients used non-steroidal anti-inflammatory drugs, and 4 patients used cardiovascular and neurological medications. No co-morbid diseases were found in 29 patients. Eight patients had a history of congestive heart failure and hypertension, 1 transient ischemic attack, 2 hypertension and cerebrovascular accident, and 10 patients had diseases concerning other systems. Other diseases included chronic illnesses such as osteoarthritis and osteoporosis.

No pathological findings were obtained in the neurological examination of 29 patients. In 21 patients pathological findings were detected; 5 patients had nystagmus, 4 ataxia, 4 ataxia and nystagmus, 4 dysmetria and dysdiadochokinesia, and 3 ataxia, dysmetria, and dysdiadochokinesia. Among 21 patients whose neurological examination yielded pathological findings, 8 had lesions associated with vertigo on MRI (Table 1).

MRI showed pathological findings associated with vertigo and abnormal neurological examinations in 8 patients. In one patient with nystagmus, MRI showed fetal posterior cerebral artery (PCA) and basilar artery with narrow calibration. Cerebellar infarction was present in 2 patients with ataxia. Subdural hematoma and subarachnoid hemorrage (SAH) was detected in one patient with dysmetria. Two patients had nystagmus and ataxia. MRI showed pilocytic astrocytoma in one of these and aberrant artery pressure on the $7^{\text {th }}$ and $8^{\text {th }}$ cranial nerves in the other patient. Ataxia, dysmetria and dysdiadochokinesia was observed in two patients; one of them had pontine demiyelinization in his MRI, and the other had cerebellar infarction.

On ENT examination of patients, 4 patients had impacted cerumen, 3 had perforated tympanic membrane, and 1 had pseudomembrane on tym- 


\begin{tabular}{|c|c|c|c|}
\hline \multirow[b]{2}{*}{ Neurological examination } & \multicolumn{3}{|c|}{ MRI } \\
\hline & Normal+ lesion not associated with vertigo & Lesion associated with vertigo & Total \\
\hline Normal & 26 & 3 & 29 \\
\hline Nystagmus & 4 & 1 & 5 \\
\hline Ataxia & 2 & 2 & 4 \\
\hline Dysmetria and dysdiadochokinesia & 3 & 1 & 4 \\
\hline Nystagmus and ataxia & 3 & 2 & 5 \\
\hline Ataxia, dysmetria and dysdiadochokinesia & 1 & 2 & 3 \\
\hline Total & 39 & 11 & 50 \\
\hline
\end{tabular}

* Marginal Homogeneity Test was used.

MRI: Magnetic resonance imaging.

panic membrane. No pathologies were found in 42 patients. In audiological tests, 21 patients had cochlear sensitivity. In hearing tests, hearing loss at low frequencies was detected in 22 patients. Audiological tests of patients with hearing loss at low frequencies and cochlear sensitivity were considered abnormal. Thirty-three patients with cochlear sensitivity and/or hearing loss at low frequencies according to audiological tests were diagnosed with peripheral vestibulopathy (Table 2). When MRI results of patients with peripheral vestibulopathy were assessed, MRI of 6 out of 33 patients revealed lesions associated with vertigo. One patient had fetal posterior cerebral artery (PCA) and narrow basilar artery, 2 had vertebral artery hypoplasia, 1 had cerebellar infarction, 1 had an abberant artery pressuring on the $7^{\text {th }}$ and $8^{\text {th }}$ cranial nerves, and 1 had subdural and subarachnoid bleeding. Of 5 patients with normal audiological tests, 3 had cerebellar infarction, 1 had mass lesion in cerebellar hemisphere consistent with pilocytic astrocytoma, and 1 had demyelinating findings on the pons (consistent with multiple sclerosis).
No pathology was detedcted in the MRI of 23 patients. Of the remaining 16 patients, 9 had nonspecific lesions, 4 had chronic ischemic gliotic lesions, 1 had parietal resorbed hematoma, 1 had lacuner infarction, and an incidental menengioma was found in 1 patient.

\section{DISCUSSION}

Various clinical conditions should be considered for the differential diagnosis of vertigo. ${ }^{3}$ Thus, for accurate differential diagnosis, it is important to evaluate and manage a patient with vertigo according to an algorythm. Prompt and exact identification of possible pathological conditions that would require emergent intervention in a patient with severe symptoms referring to the ER is crucial. In addition, identification and treatment of the underlying pathology in the fastest and cheapest way is important for cost-effectiveness. Studies show that the patient's history is very useful in differentiation of central and peripheral causes of vertigo. ${ }^{10}$ In patients with chronic recurrent vertigo attacks, physical examination and vestibular func-

\begin{tabular}{|lccc|}
\hline \multicolumn{4}{|c|}{ TABLE 2: Comparison of audiological test results and MRI $\left(x^{2}=15.125, p=0.000\right)^{*}}$. \\
\hline & & & \\
& & & \\
Audiology & Normal+ lesion not associated with vertigo & Lesion associated with vertigo & Total \\
Audiology normal & $12(70.6 \%)$ & $5(29.4 \%)$ & $17(100 \%)$ \\
Audiology abnormal & $27(81.8 \%)$ & $6(18.2 \%)$ & $33(100 \%)$ \\
Total & $39(78 \%)$ & $11(22 \%)$ & $50(100 \%)$ \\
\hline
\end{tabular}

${ }^{*}$ Mc Nemar Test was used.

MRI: Magnetic resonance imaging. 
tions are usually normal. ${ }^{10}$ In our study, of the 24 patients with a history of recurrent vertigo attacks, neurological examination was normal in only 13 and vestibular tests were consistent with peripheral vestibulopathy in 16 patients.

We evaluated hearing in low frequencies and cochlear sensitivity with audiovestibular tests in order to identify the causes that could lead to vertigo. Cochlear sensitivity is defined as disturbance at a sound intensity below 90 decibels. The presence of hearing loss at low frequencies and cochlear sensitivity favors the diagnosis of peripheral vestibulopathy. In this condition, no MRI is required except for some selected cases. However, Mark AS et al. reported in their study that pathologies with central origin were found in some cases in which MRI was not required. ${ }^{11}$ In our study, MRI of 6 out of 33 patients with peripheral vestibulopathy revealed a central lesion associated with vertigo. Although the difference between pathologies identified with MRI and abnormal audiovestibular tests was not significant, there was clinical significance.

In a patient with vertigo, after detailed physical and neurological examination, neuroradiological imaging techniques that may be selected are CCT, MRI and magnetic resonance angiography (MRA). The role of imaging techniques in patients with peripheral vertigo is a debate. ${ }^{12} \mathrm{CCT}$ and MRI are techniques that are usually used for definitive diagnosis. CCT and MRI should be considered in suspected cases after a detailed clinical examination. ${ }^{12}$ Among these two techniques, MRI is shown to be the first choice in central vertigo. ${ }^{12-15}$

In our study, among 50 patients, 23 had no pathology, 16 patients (32\%) had lesions not associated with vertigo, and 11 patients (22\%) had lesions associated with vertigo (Table 3 ). Our results suggest the importance of assessing a vertigo patient with MRI. MRI detected lesions associated with vertigo in 11 out of 42 patients with normal ENT examination and 3 out of 29 patients with normal neurological examination. Although our results did not yield statistical significance, this needs to be reevaluated in studies with larger series be-
TABLE 3: MRI findings of patients associated with vertigo.

\begin{tabular}{|lcl|}
\hline Gender & Age & MRI Findings \\
M & 18 & Pilocytic astrocytoma \\
M & 35 & Cerebellar infarction \\
M & 37 & Fetal PCA, narrow basilar artery \\
F & 17 & Demyelinization in brain stem \\
F & 50 & Vertebral artery hypoplasia \\
F & 52 & Cerebellar infarction \\
F & 55 & Vertebral artery hypoplasia \\
F & 50 & Cerebellar infarction \\
M & 85 & Cerebellar infarction \\
M & 84 & Aberrant artery pressing on the $7^{\text {th }}$ and $8^{\text {th }}$ nerve \\
M & 60 & Subdural hematoma + SAH on right cerebral cortex \\
\hline
\end{tabular}

M: male, F: female; MRI: Magnetic resonance imaging;

PCA: Posterior cerebral artery; SAH: subarachnoid hemorrage.

cause lesions detected with MRI have clinical significance. In a prospective study performed by Norrving B et al, similar to the results in our study, one out of every 4 patients with isolated acute vertigo, clinical misdiagnosis led to overdiagnosis of caudal cerebellar infarction. ${ }^{16}$

Our results suggest that, neurological examination and audiovestibular findings may not always be sufficient to differentiate the underlying pathology and MRI technique can provide important findings for the diagnosis. ${ }^{17}$ Larger studies are needed to see if MRI also has a potential to present statistically significant differences in the detection of clinically important pathologies more accurately and earlier.

As we found in our study, $10 \%$ of patients with normal neurological examination had lesions on MRI. Therefore, meticulous neurological examintaion can exclude the majority of central vertigo patients.

\section{LIMITATIONS}

Due to the small sample size in the current study, we can not make a clear statement regarding the value of MRI and audiology in the differentiation of peripheral versus central vertigo in the Emergency Department. Further studies including larger sample sizes are needed. 


\section{REFERENCES}

1. Walker JS, Barnes SB. Dizziness. Emerg Med Clin North Am 1998;16(4):845-75, vii.

2. Karataş M. [Vertigo in the Emergency Department]. Turkiye Klinikleri J Surg Med Sci 2007;3(37):61-70.

3. Selekler K. [Vertigo and causes]. Turkiye Klinikleri J Med Sci 1983;3(2):179-82.

4. Drachman DA. Clinical crossroads. Conferences with patients and doctors Beth Israel Deaconess Medical Center. J American Med Association 1998;24(1):23-30.

5. Nedzelski JM, Barber HO, Mcllmoyl L. Diagnoses in a dizziness unit. $\mathrm{J}$ Otolaryngol 1986;15(2):101-4.

6. Ceylan A, Tutar H. [Medical treatment of vertigo]. Turkiye Klinikleri J Surg Med Sci 2006;2 (49):30-4.

7. Almaç A, Canbay E. [Benign positional vertigo]. Turkiye Klinikleri J Med Sci 1987;7(6): 562-7.
8. Staab JP. Chronic dizziness: the interface between psychiatry and neuro-otology. Turkiye Klinikleri J Neurol 2008;3(1):48-58.

9. Ensari N, Göksu N. [Approach to dizziness]. Turkiye Klinikleri J Surg Med Sci 2006;2(28): 43-58.

10. Baloh RW. Differentiating between peripheral and central causes of vertigo. Otolaryngol Head Neck Surg 1998;119(1):55-9.

11. Mark AS, Seltzer S, Nelson-Drake J, Chapman JC, Fitzgerald DC, Gulya AJ. Labyrinthine enhancement on gadoliniumenhanced magnetic resonance imaging in sudden deafness and vertigo: correlation with audiologic and electronystagmographic studies. Ann Otol Rhinol Laryngol 1992;101(6):459-64.

12. Bruzzone MG, Grisoli M, De Simone T, Regna-Gladin C. Neuroradiological features of vertigo. Neurol Sci 2004;25(Suppl 1):S20-3.
13. Louryan $\mathrm{S}$. [Diagnostic imaging of peripheral vertigo]. Rev Med Brux 2002;23(4):A363-7.

14. Park SU, Kim HJ, Cho YK, Lim MK, Kim WH, Suh $\mathrm{CH}$, et al. The usefulness of MR imaging of the temporal bone in the evaluation of patients with facial and audiovestibular dysfunction. Korean J Radiol 2002;3(1):16-23.

15. Casselman JW, Kuhweide R, Dehaene I, Ampe W, Devlies F. Magnetic resonance examination of the inner ear and cerebellopontine angle in patients with vertigo and/or abnormal findings at vestibular testing. Acta Otolaryngol Suppl 1994;513:15-27.

16. Norrving B, Magnusson M, Holtås S. Isolated acute vertigo in the elderly; vestibular or vascular disease? Acta Neurol Scand 1995;91(1): 43-8.

17. Akpınar Z. [Vestibular tests and their interpretation: review]. Turkiye Klinikleri J Med Sci 2005;25(5):724-31. 